ppi $201502 Z U 4645$

Esta publicación científica en formato digital es continuidad de la revista impresa ISSN-Versión Impresa 0798-1406 / ISSN-Versión on line 2542-3185Depósito legal pp $197402 Z$ U34
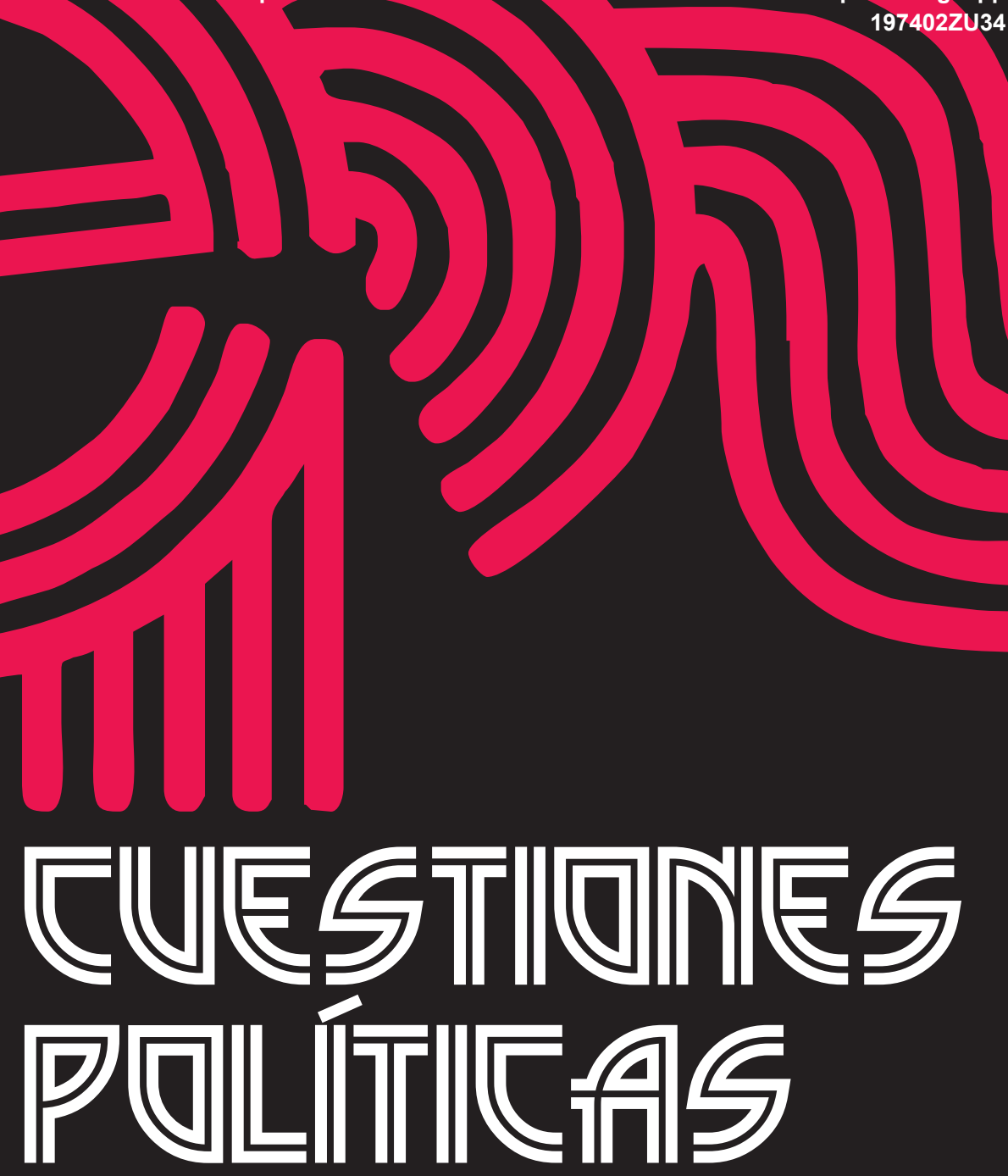

Instituto de Estudios Políticos y Derecho Público "Dr. Humberto J. La Roche" de la Facultad de Ciencias Jurídicas y Políticas de la Universidad del Zulia Maracaibo, Venezuela
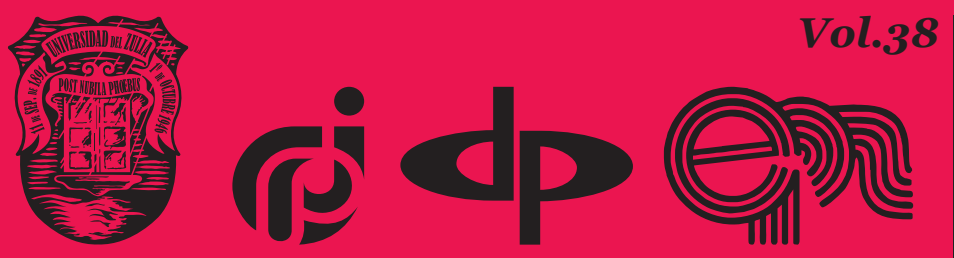

$N^{\circ}$ Especial 2da Parte 2020 


\title{
Social and legal guarantees of the rights of convicts according to the legislation of the Russian Federation
}

\author{
DOI: https://doi.org/10.46398/cuestpol.382e.23
}

\author{
Lyaysan Renatovna Mustafina * \\ Gulnara Mullanurovna Khamitova ** \\ Gulnara Ildarovna Nafikova ***
}

\begin{abstract}
The objective of the article is to examine the social and legal guarantees of the rights of convicts under the legislation of the Russian Federation. The socio-documentary method was used. The square of the subject lies in the development of a system of social protection of the population in prison institutions. After all, convicts, like other people, need social protection and social security from the state. Upon entering the prisons, they experience adaptation and have no idea of the existence of certain legal and legal social guarantees. Supporting a segment of the population as convicted requires social and legal guarantees, thus improving the conditions of their service in places of deprivation of liberty. Places of deprivation of liberty are counted, because social work aimed at supporting these categories of population, such as the elderly and mothers, adheres to places of deprivation of liberty, because social work is oriented precisely to these categories of population, where necessary, as well as to protect motherhood, fatherhood and children and, inmates, have much to contribute in these areas and social segments
\end{abstract} if they meet.

Keywords: social protection; social security of the condemned; social and legal guarantees; places of deprivation of liberty; prison system.

\footnotetext{
Assistant of the Department of constitutional and administrative law in Kazan Federal University, ORCID ID: https://orcid.org/oooo-0oo1-8294-9209. Email: leisanm81@mail.ru

** PhD in law, Associate Professor of Medical Law Department in KazanState Medical University. ORCID ID: https://orcid.org/oooo-0oo3-4167-2279. Email: gulnarakgmu@mail.ru

*** $\mathrm{PhD}$ in law, Associate Professor of Criminal Law Department in The University of Management “TISBI". ORCID ID: https://orcid.org/oooo-0oo2-1186-3886. Email: pravovoy-status.kzn@yandex. $\mathrm{ru}$
} 
Lyaysan Renatovna Mustafina, Gulnara Mullanurovna Khamitova y Gulnara Ildarovna Nafikova

304

Social and legal guarantees of the rights of convicts according to the legislation of the Russian Federation

\section{Garantías sociales y legales de los derechos de los condenados según la legislación de la Federación de Rusia}

\section{Resumen}

El objetivo del artículo es examinar las garantías sociales y legales de los derechos de los condenados según la legislación de la Federación de Rusia. Se empleó el método sociológico y documental. La relevancia del tema radica en el desarrollo de un sistema de protección social de la población en las instituciones penitenciarias. Después de todo, los convictos, al igual que otras personas, necesitan recibir protección social y seguridad social del estado. Al ingresar a las instituciones penitenciarias, experimentan dificultades de adaptación y no tienen ni idea de la existencia de ciertas garantías sociales y legales. Apoyar a un segmento de la población como condenado requiere garantías sociales y legales adicionales, mejorando así las condiciones de su servicio en los lugares de privación de libertad. Se concluye que, los sujetos objetivo de la obra social, como los discapacitados, los ancianos y las madres, acceden a los lugares de privación de libertad, porque la obra social está orientada precisamente a apoyar a estas categorías de población, cuando sea necesario, así como a proteger la maternidad, la paternidad y la infancia y, los reclusos, tienen mucho que aportar en estas áreas y segmentos sociales si se crean las condiciones para ello.

Palabras clave: protección social; seguridad social de los condenados; garantías sociales y legales; lugares de privación de libertad; sistema penitenciario.

\section{Introduction}

The areas of social work in the penitentiary sphere include pensions, provision of benefits, social services, gratuitous and preferential provision of drugs for convicts, assistance in household and work placement, as well as the creation of social institutions, such as medical units in colonies and orphanages (Vladimirova and Iutiaeva, 2018). The main statutory rights of convicts include the right to health protection and personal safety and the right to social security and insurance (The decree of he RF government of No. 727, 2001.).

Persons sentenced to places of deprivation of liberty have some social and legal guarantees, which are specified in the Criminal Executive Code of the Russian Federation (CEC RF) (Khamitova and Gimadieva, 2019). This law contains the rules of social orientation in relation to convicted 
and released convicts. According to Article 7 of the Constitution of the Russian Federation, the Russian Federation is a social state, with the policy aimed at creating conditions that ensure a dignified life and free human development. This means that the state protects labor and health of people, establishes a guaranteed minimum wage, provides a state support for family, motherhood, fatherhood and childhood, disabled people and elderly citizens, develops a system of social services, and establishes state pensions, benefits and other guarantees of social protection (The Constitution Of The Russian Federation As Amended As Of, 2018). And convicts are no exception. They are also entitled to receive pension benefits, regardless of the fact that they are in detention.

\section{Methods}

The research is based on the method of analysis of the current Russian legislation and law enforcement practice and existing European (world) standards for the purpose of legal unification (Gutteridge, 1974). Methods of legal modeling and forecasting make it possible to determine the need for amendments to the existing Russian regulations, as well as the need to adjust judicial practice (Dale, 1977). Through the use of modeling and forecasting methods, the consequences of such changes and adjustments can be established with a sufficient degree of reliability, as well as it is revealed how, ultimately, Russian law enforcement practice will be close to the existing European (world) standards (Arslanov and Khabirov, 2017).

The legal sociological method provides for the assessment of social problems from a legal position, from the position of the legislator and law enforcement officer (Mathias and Daith, 2012). The method of interpretation complements the comparative legal analysis in the study, making it possible to understand and compare Russian and European (world) legal standards (Davies, 2016). The use of various methods made it possible to formulate the main theoretical conclusions and make their own proposals on the investigated sphere of social relations (Criminal executive code of the Russian federation, 2019).

\section{Results and Discussion}

Thus, the CEC RF enshrines the principles of compulsory state social insurance and pension provision for those sentenced to imprisonment. The most important thing is that convicts sentenced to imprisonment, involved in labor, are subject to compulsory state social insurance, and convicted 
Lyaysan Renatovna Mustafina, Gulnara Mullanurovna Khamitova y Gulnara Ildarovna Nafikova

Social and legal guarantees of the rights of convicts according to the legislation of the Russian Federation

women are also provided with maternity benefits in the manner established by the Government of the Russian Federation. Convicts have the right to state pensions in old age, in case of disability, loss of a breadwinner and in other cases stipulated by the legislation of the Russian Federation (The decree of he RF government of No. 727, 2001). State pensions in old age are paid to convicted men who have reach 65 years of age and women who have reached 60 years of age. The pension is credited to the personal account of the convict, however, deductions are made from it to reimburse the expenses for its maintenance. In addition, the law establishes the right to compensation for damage to the convict in case of his/her loss of ability to work while in prison. Moreover, this right is exercised immediately, as soon as incapacity for work occurs.

According to Article 103 of the Criminal Code of the Russian Federation, every convict is obliged to work in places and jobs determined by the administration of correctional institutions. At the same time, according to the internal regulations of correctional institutions, it is prohibited to use the labor of convicts as drivers of operational vehicles, salesmen, accountants, cashiers, in departments for the execution of sentences and other units of ministries and departments of the penal system, in headquarters and premises where penitentiary personnel is accommodated and weapons and service documentation is stored, for work related to duplicating, radiotelegraph, telephone, telefax equipment, as well as to accounting, storing and issuing medicines, explosives and toxic substances. Convicts also usually do not work with sophisticated and expensive equipment. Convicted men and women who have reached retirement age and convicts with disabilities may work voluntarily (Criminal executive code of the russian federation No. 1-FZ. 2019).

The working conditions are legally established: working hours of those sentenced to imprisonment, labor protection rules, safety measures and industrial sanitation. Working convicts have the right to annual paid leave: 18 working days for those serving sentences in educational colonies and 12 working days for those serving sentences in other correctional institutions. The aforementioned leave is granted either with or without travel outside the penitentiary facility (Criminal executive code of the russian federation No. 1-FZ. 2019). Convicts have the right to remuneration, the amount of which cannot be lower than the established minimum wage if the monthly norm of working time is fulfilled and in proportion to the time worked by the convicted person or depending on the work done during part-time or part-time working week.

The provision of benefits and compensations to convicts is enshrined in the Government Decree of October 15, 2001 No. 727 «On the procedure for providing benefits for compulsory state social insurance to persons sentenced to imprisonment who are involved in paid work», according to 
which convicts have the following types of compulsory social insurance benefits:

1. For temporary disability (except for industrial accidents and occupational diseases).

2. For pregnancy and maternity.

3. A one-time benefit to women registered at a hospital in the early stages of pregnancy (up to 12 weeks).

4. A one-time benefit for the birth of a child (except for cases when the children of convicts are fully supported by the state).

5. Monthly childcare benefit (in case of serving a sentence in penal colonies) (The decree of he RF government of No. 727, 2001).

All of the above benefits are paid to convicts at the expense of insurance contributions for compulsory social insurance in case of temporary disability and in connection with maternity to the Social Insurance Fund of the Russian Federation by organizations in which convicts work. Convicts have the right to the benefits specified in paragraphs 1-3 if, before they were released from work, they performed their labor duties in accordance with the established work schedule. Temporary disability benefit is issued in case of a disease associated with disability (The decree of he RF government of No. 727, 2001). The size of the temporary disability benefit ranges from 60 to 100 percent of the average wage of a convict. However, there are some exceptions, which are also indicated in this Regulation. For example, temporary disability benefits are not assigned:

1. for the period of discharge of the convict from job with full or partial retention of wages or without payment pursuant to the applicable laws of the Russian Federation, except for the cases of disability due to illness or injury during the period of annual paid leave;

2. for the period of suspension from job pursuant to the applicable laws of the Russian Federation, provided no wages were accrued for this period;

3. for the period of inactivity, except for the cases of temporary disability that occurred before the period of inactivity and continues during the period of inactivity;

Grounds for refusal to pay temporary disability benefit to the convict may be:

1. occurrence of the temporary disability as a result of the determined by court willful damnification by the convict of his/her health or attempted suicide; 
Lyaysan Renatovna Mustafina, Gulnara Mullanurovna Khamitova y Gulnara Ildarovna Nafikova

Social and legal guarantees of the rights of convicts according to the legislation of the Russian Federation

2. occurrence of the temporary disability as a result of the willful crime committed by the convict (The decree of he RF government of No. $727,2001)$.

In addition to benefits and pensions, the legislation also stipulates the material and household support of convicts. They are provided with individual sleeping places and bedding. They are provided with seasonal clothing, taking into account gender and climatic conditions, and with personal hygiene products. The minimum food standards and material and living conditions for convicts are established by the Government of the Russian Federation. At the same time, at the expense of enterprises that attract convicts to work, they can be provided with additional food in excess of the norm established by the Government. Inmates excused from work because of illness or because they are pregnant or breastfeeding are fed free of charge during this period. Food, clothing, basic amenities and personal hygiene items are provided free of charge to convicts in young offender institutions and convicts with category I or category II disability.

According to the CEC, those sentenced to imprisonment have the right to vocational education and training. Convicts who do not have a profession are provided with compulsory primary vocational education or vocational training in the penitentiary institutions. The convict will be able then to work in the penitentiary institution and after his/her release. Prisoners have the right to receive long visits for close relatives, lasting 3 days, and short-term visits for relatives and other persons, lasting 4 hours, as well as to receive parcels or book posts.

Their number is determined depending on the institution the convict stays in. For example, convicts in minimum-security penitentiary institutions are granted six short-term visits and four long-term visits during the year and 6 parcels and 6 book posts, provided that the convict has not violated the internal order. However, convicted women or convicted men who have a child under the age of 14 and who are the only parent may be provided with additional long-term visits with the child on weekends and holidays, with living outside the correctional institution, but within the municipality where the correctional institution is located. if it is provided for by the conditions of serving imprisonment in a correctional institution Upon serving a certain part of the term, on legal grounds, convicts are entitled to parole. The time required for compulsory serving is determined depending on the severity of the crime committed (Order of the ministry of justice of russia of december 16 No. 295 "On approval of the Internal Regulations of Correctional Institutions, 2016).

The administration of penitentiary institutions must facilitate the work and living arrangements of the released convicts. 2 months before the expiration of the term of arrest or 6 months before the expiration of the term of imprisonment, the administration of the institution executing the 
sentence notifies the local government and the federal employment service at the place of residence chosen by the convict about his/her forthcoming release, the availability of housing, available specialties and his/her ability to work. At the same time, disabled convicts and convicts who have reached retirement age can apply to the administration with a request to send them to homes for the elderly and disabled.

Convicts released from forced labor or imprisonment for a certain period are provided with free travel to their place of residence, they are provided with food or money for the duration of the trip. In the absence of clothing necessary for the season or funds for its purchase, convicts released from prison are provided with clothing at the expense of the federal budget. Convicted persons in need of nursing care for health reasons, convicted pregnant women and women with young children, as well as convicted juveniles who are not able to independently, without assistance, get to their place of residence, the administration of the institution executing the punishment informs in advance about their release of relatives or other persons.

\section{Summary}

A systematic analysis of the current legislation allows us to conclude that all convicts, without any discrimination, have social and legal guarantees for health care, benefits, allowances, pensions and other types of social protection while in the penitentiary institutions. Moreover, convicts in the penitentiary facilities are entitled to short and long term visits with relatives and, most importantly, to parole. At the same time, the administration of the institution executing the punishment contributes to the further employment and living arrangements of the released prisoners. After all, all released convicts have the right to a labor and household arrangement and to receive other types of social assistance in accordance with the legislation of the Russian Federation and regulatory legal acts.

\section{Conclusions}

However, despite all the aforementioned possibilities, there are a number of social needs, the introduction of which into legislation will best guarantee the listed above rights. In particular, proposals are being made to amend Article 89 of the Criminal Executive Code of the Russian Federation, dedicated to motherhood and childhood, on granting a woman who gave birth at the time of imprisonment in a correctional facility an additional 
Lyaysan Renatovna Mustafina, Gulnara Mullanurovna Khamitova y Gulnara Ildarovna Nafikova

310

Social and legal guarantees of the rights of convicts according to the legislation of the Russian Federation

long visit for up to 6 days in order to have the opportunity to meet with his/her family (Afletonova and Khamitova, 2018). A similar rule should be provided for male prisoners, who should have the right to a full meeting with their wife and newborn child who are at large.

\section{Acknowledgments}

The work is performed according to the Russian Government Program of Competitive Growth of Kazan Federal University.

\section{Bibliographic References}

CRIMINAL EXECUTIVE CODE OF THE RUSSIAN FEDERATION.2019.No. 1-FZ of 08.01.1997. Available online. In: http://www.consultant.ru. Consultation date: 16/11/2019.

AFLETONOVA, Alex; KHAMITOVA, Gulnara M. 2018. Social protection of orphans and children left without parental care. Proceedings of the VII International Scientific and Practical Conference dedicated to the 2oth anniversary of the Department of Social Technologies of the East Siberian State University of Technology and Management. In the collection: Forms and methods of social work in various spheres of life. Chief editor Iu.Iu. Shurygin.

ARSLANOV, Kamil Maratovich; KHABIROV, Artur Ilfarovich. 2017. "About the Weak Party of the Loan Contract” In: Comparative Law. No 4, pp. 10-23.

DALE, William. 1977. Legislative drafting: a new approach: a comparative study of methods in France, Germany, Sweden and The United Kingdom. Cambridge university press. Cambridge, United Kingdom.

DAVIES, Paul. 2016. Rectification Versus Interpretation: The Nature and Scope of the Equitable Jurisdiction'. CLJ, 75, 62-85.

GUTTERIDGE, Harold Cooke. 1974. "Comparative law: an introduction to the comparative method of legal study and research" CUP Archive. In: The Cambridge Law Journal. Vol. 9, No. 3, pp. 386 - 387.

KHAMITOVA, Gulnara; GIMADIEVA, Rayan. 2019. Analysis of the elaboration of the regulatory framework of the Russian Federation on paid social 
services. Social and Pension Law. Kazan State Medical University. Kazan, Russia.

KHOLOSTOVA, Elena. 2018. Russian encyclopedia of social work. - 3rd ed. «Dashkov and Co" Publishing and trade corporation. Moscow, Russia.

MATHIAS, Markus; DAITH, Mikel. 2012. "Mapping Legal Research" In: Cambridge Law Journal. Vol. 71, No. 3, pp. 651-676.

ORDER OF THE MINISTRY OF JUSTICE OF RUSSIA OF DECEMBER 16, 2016, No. 295 "On approval of the Internal Regulations of Correctional Institutions" . Available online. In: http://www.consultant.ru/. Consultation date: 16/11/2019.

THE CONSTITUTION OF THE RUSSIAN FEDERATION AS AMENDED AS OF. 2018. Eksmo. Moscow, Russia.

THE DECREE OF HE RF GOVERNMENT OF No. 727. 2001. «On the procedure for providing benefits for compulsory state social insurance to persons sentenced to imprisonment who are involved in paid work". OF OCTOBER 15, 2001. Available online. In: http://www.consultant.ru/. Consultation date: 16/11/2019.

VLADIMIROVA, Oilika; IUTIAEVA, Loura. 2018. Social work with convicts: textbook. Samara Law Institute of the Federal Penitentiary Service of Russia. Samara, Russia. 

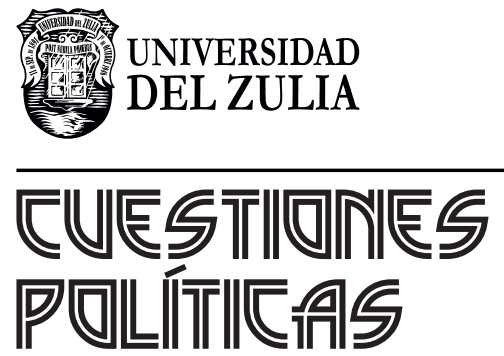

Vol.38 NEspecial

Esta revista fue editada en formato digital y publicada en diciembre de 2020, por el Fondo Editorial Serbiluz, Universidad del Zulia. Maracaibo-Venezuela 